Received: Octobre17, 2014. Accepted: January 9, 2015

\title{
Does the change have to be revolutionary? August Cieszkowski's philosophy of future
}

\section{MARCIN LISIECKI}

Uniwersytet Mikołaja Kopernika w Toruniu

Marcin.Lisiecki@umk.pl

\begin{abstract}
The main purpose of this article is analysis of question of future in philosophy of August Cieszkowski. Amog Polish philosophers Cieszkowski was one of the most important thinker, who creatively developed the philosophy of George Hegel, added new question, such as "future". For clarity of analysis the essay is divided into two parts. The first part is connected with problem of future in Cieszkowski's philosophy with references to social and religious fields. The second one included analysis of relations between social and religious changes and revolution.
\end{abstract}

Keywords: August Cieszkowski; George Hegel; Young Hegelians; future, revolution; religion; social change.

There was nothing I had considered more than the concept of destiny Charles Fourier, Théorie des quatre mouvements

August Cieszkowski having emerged in the world-wide philosophy was the event that must be regarded as exceptional. That - almost panegyric - judgment results mainly from the importance of his thought and from the fact that he is apparently the only Polish XIX-century philosopher recognized and highly valued abroad. We can also claim that he is much more 
popular with Western philosophers than in Poland. As a philosopher, Cieszkowski was appreciated mainly for his work Prolegomena to a Historiosophy (Prolegomena zur Historiosophie, 1838), in which he included a couple of essential thoughts related to the revision of Georg W. F. Hegel's philosophy. It is to be emphasized that Cieszkowski, representing quite a unique understanding of Heglism, inspired the philosophers belonging to the socalled Left Hegelians. Thus, he contributed to the ambiguous evaluation of his relations with Young Hegelians and with the influence on the thought by Moses Hess and Karol Marx. Even more so because his later works, such as God and Palingenesis (Gott und Paligenesie, 1842) or Our Father (Ojcze Nasz, 1848-1906) are concerned with the issues plainly unacceptable for Young Hegelians.

The attractiveness of Cieszkowski's philosophy involves its ambiguity or even the multitude of threads included in his works. It is attractive not only in the context of making an attempt to conduct the synthesis of his thought but also - and primarily so - in the sense of reading his works as vital for contemporary philosophy (social philosophy inclusive) ${ }^{1}$. We can observe it in the question of future, tackled by Cieszkowski, future proving to be one of the fundamental threads under consideration in his works. The question of future is also a thread referring to the question of change (including revolution) and a few other minor issues. It should be emphasized that undertaking the discussion of such problems contributed to the growth of popularity of Cieszkowski's works - mainly with Young Hegelians but it also cause the severe criticism on the part of Catholic writers (cf. Jakubowski 1989, 146; Keller 1948, 42; Sojka 1986, 21). The consequence of the above fact is that from a few dozen years, the analysis of Cieszkowski's philosophy causes major troubles related to opposing evaluations of his major works, that is Prolegomena to a Historiosophy and

1 The clear example of such resemblances may be the representatives of Frankfurt School, mainly Max Horkheimer - in the criticism of progress and Alex Honneth in his concept of "recognition". It is worthwhile to compare Cieszkowski's writings with Critique of Instrumental Reason of Horkheimer and The Struggle for Recognition: The Moral Grammar of Social Conflicts of Honneth. 
Our Father. The discrepancies between those evaluations resulted mainly from the fact, that generally one of the facets of Cieszkowski's philosophy was accentuated. The aim was to connect the concept of "future" with "change", which could be both understood in the spirit of Young Hegelians or Marxism as revolution. On the other hand, what is important here is the decisively different evaluation expressed in religious categories and not related to social or political issues. We can also suppose that the lack of consensus between researchers stemmed to a large extend from the ideological orientation of the research, which impeded the general overview of Cieszkowski's philosophy. What counts in favour of assuming such a viewpoint is the words of the philosopher himself saying that he cherished leitmotif thought expressed most fully in Our Father. Thus, he replied to his son: "Whatever I had written since then, Our Father being my everything, belongs to that work, refers to it or departs from it [...]. Everything - these are branches of one tree, Yet, once in a while I departed from the trunk and worked on its twigs" (Cieszkowski 1908, II). Taking the above-stated words as a hypothesis, we might claim that these two facets of his philosophy do not have to be mutually contradictory; they can in fact complement one another. And the key to the general understanding of Cieszkowski's philosophy is the concept of "future", which combines the religious issues with the concept of change. That is why, we might justifiably use the formulation "philosophy of future" and make it an interesting and scientifically important thread in the thought of the Polish philosopher.

\section{Understanding of the concept "future"}

The departure point for understanding the foundations of August Cieszkowski's philosophy of future is the philosophical system by Hegel and more strictly speaking: Hegelian resistance to events which have not occurred yet. That fear was so characteristic of his philosophy that only when the distant future was gradually becoming "the painful present" he had to mark it with the status of "rationality. In Leszek Kołakowski's opinion, Hegelian rationalism even forbids the philosophy from thinking of what is 
yet to come and forces it to remain satisfied with understanding of what had already happened (Kołakowski 2000, 105). It means that the present is worth recognizing as valid when it overwhelms us with its necessity thus disabling keeping the so-far theoretical indifference to present events. The most conspicuous example of accepting the present and the fear of future is Hegel's attitude towards French revolution, which he recognized only at the moment of its spread-out. Jürgen Habermas draws our attention to the fact that Hegel, enclosing the revolution in the beating heart of the spirit of the world, felt that he is not threatened by it (Habermas 1983, 153). Hegelian fear of future is here equivalent with the fear of the change, which being quite difficult to control and to be conceptualized in terms of dialectics. We must emphasize the fact that it is Hegelian dialectics in which the essence for understanding Cieszkowski's philosophy of future lies. Revaluating dialectics, he addressed the drawbacks in Hegelian system causing the state of being constrained within the limits of the past and the tamed present. In Cieszkowski's opinion, such a state of affairs is unacceptable because we cannot affirm that history is terminated when the present takes effect and neither can we posit that history will be no longer subject to further development (Cieszkowski 1972, 5). That is why he postulated that the process of grasping the essence of history must encompass both past, present and the future. (Cieszkowski 1972, 7).

The revision of Hegelian thought singled out "future" and made it one of the most important concepts in Cieszkowski's philosophy. However, in Prolegomena to a Historiosophy that issue is not expressed so vividly as in Our Father and it refers mainly to the complementation of Hegelian dialectics. Introducing the concept of "future", he thought that it is necessary to the general grasp of the evolution of history. It led to the dismissal of Hegelian four-fold division position assumed by Hegel and transforming it into the trychotomic division embracing: antique (the epoch of arts), the present (the epoch of thought) and future (the epoch of act) (Walicki 1972 , XII). In his opinion, the present introducing the epoch of thought, as Hegel insisted, cannot mean the end of history because it is at odds with dialectics. Secondly, the preset encompasses the introduction of forth- 
coming events, which cannot be overstated. The present is the transitory period, the bridge leading to future events (Keller 1948, 76). The reason to assume that almost prophetic position is the chiliastic tradition of threestage evolution of history assumed by utopian socialists, mainly by Henri de Saint-Simon and Charles Forurier. One cannot lose out of sight the messianic romanticism based on the belief that there are other non-rational factor operating and the faith in the new epoch of human happiness and the definitive defeat of the evil by the good (Keller 1948, 21). We can add that what Cieszkowski mainly meant - as in the case of other romanticists - was the predicament Poland was caught in, and that is the attempts to fight for independence of it.

Searching for the key to the correct interpretation of the philosophy of future as well as allocating to it the locus in the world philosophy, we can make use of the paraphrase of the words by Karol Marx originating from Theses on Feuerbach, and having it that philosophers differently described the past but the point is to focus on the future 2 . Substituting "past" for the word "interpretation" and "future" for "change" seems understandable or even obvious. For a change to be implemented, there must be some future looming. The future should transcend what was introduced by the past and what was maintained by the present. However, Marx' thought, though it has the far-reaching implications in the form of revaluations in the realm of social investigations (to a greater degree than in the realm of philosophy), when referred to Cieszkowki's works acquires the greater depth of scientific reflection. It results from the fact that Marxian "change" does not refer to the "future" in the sense Cieszkowski's described the issue. That fact must be underlined because by combining "future" with "change", he introduces the concept of "act", which (in his sense of it) refers us not only to the realm of praxis, but most of all to episteme.

From the above, there seems to emerge the necessity to delineate the possibility of knowing the future appealing to the framework of dialectics. As Cieszkowski put it in Prolegomena to a Historiosophy:

2 What is meant is the well-known thesis 11: "The philosophers have only interpreted the world, in various ways; the point is to change it” (Marks 1975, 8). 
past manifests the depth and generality contained in it and it shows how perfectly its essence is expressed in the very fact of existing. On the other hand, as for the future, we can only explore the essence of progress because the possibility of implementations are so vast; the freedom and the enormity of Spirit so great that we are always in danger that reality in its detail will either overtake or at least frustrates our expectations (Cieszkowski 1972, 9).

We can claim that - similarly to Hegel - for Cieszkowski the future seemed to be shrouded in the mist of mystery but still fearful. However, it is the case only when the enquires about the future are oriented at searching for details and not its essence, which can be only cognized (Cieszkowski 1972: 9). The very process of cognizing it may be realized two-fold: rationally or by means of prophecies (Keller 1948, 77-78). It is to be stressed that addressing these two mutually contradictory ways of cognizing the future results from the analysis of the contents of Prolegomena to a Historiosophy and Our Father, in which Cieszkowski drew our attention to other methods of reaching what is unknown. In the first case, the reason is able to discover the future thanks to dialectics, which points to the future as a necessary stage transcending the past and the present. Józef Keller went as far as to claim that the future is yet unfulfilled truth which can be discovered by resorting to dialectical principles themselves (Keller 1948, 76) 3 . On the other hand, Our Father contains a religious aspect of cognizability of the future. It is related to the faith in the emergence of the new epoch understood as the emergence of "The Kingdom of Heaven" on Earth. Awaiting the materialization of that better new world stems from the chiliastic faith in the successive period of history as well as from the prayer, which, in Cieszkowski's opinion, contains some hope for the advent of the new epoch. The prayer, described in Our Father, is described as the perfect example of the awareness of anticipating the new times. The philosopher compares it with the request which contain the desire to possess what we don't have yet; what we miss and what we except from the future. (Cieszkowski 1922, 12). However,

3 Cieszkowski's account was based on the account of Johann Gottlieb Fichte, who postulated the possibility of cognizing the future through understanding the past and the present (cf. Keller 1948, 76). 
the hope for "the happier tomorrow" does not refer to individual wishes but to communal ones, which are supposed to make future gain the same status and significance as the past and the present (cf. Cieszkowski 1922, 13).

Going back to Prolegomena to a Historiosophy, it should be noted that basing the considerations on dialectics was to guarantee cognizing the future and not conjecturing which form the future might assume. That is why Cieszkowski wrote that "we are not aiming at guessing one or the other detail, that is at the prophecy related to a given agent or an act but the aim is to explore the proper nature of humanity and to define the law governing its progress" (Cieszkowski 1972, 10). Thus, he points to the concept of "prophecy", which introduces the critical difficulty in proving the consistency in his thoughts. What we mean here is that the "prophecy" is identified with "conjecturing", that is non-scientific method of learning about the possible future. That method, which we can call "conjecturing" is cognitively useless because it is not subject to the law of dialectics. Cieszkowski also maintained that dialectics, being consistent with scientific methods, for example paleontology, enables to infer the future from the past (cf. Cieszkowski 1972, 10-11; Walicki 1972, XII). Furthermore, we can point to the complexities resulting from the negative nature of "prophecy" which emerges from the its juxtaposition with "foretelling"4 It turns out that the negatively characterized "prophecy" is identical with "foretelling", the latter being conceptualized as the way of cognizing the future. We can suppose that the incoherence between these two methods of cognition results from the fact that in those opposite ways - and not fully in accordance with each other - he characterized the future in his main works. There is another interpretation possible. Namely, focusing our attention on the dialectical model of inferring the future from the past and the present and searching in them the hints of the future, he pointed to two planes in which the future might be realized. What we mean here is a social and spiritual dimension, both planes calling for proving the dimensions of their transformations. What is more, following the thought of Cieszkowski's, we can

4 Foretelling, as assumed by Keller, is contained in the prayer (cf. Keller: 1948: 79).

ScientiaetFides 3(1)/2015 
do the valuing of the attitudes expressed in social (and political one above all) and spiritual awaiting of the future. The priority is given to the prophecy included in the prayer Our Father, because it gives hope for a better fate. On the other hand, the future inferred from the dialectics does not offer that; what is more, it may prove to be more intolerable than the present.

\section{The concept of total change}

Undertaking the analysis of the concept of "future", we should always keep in mind that the concept has some explicit interrelations with the concept of "change". In any case, that is the fact in which we might notice the consistency between Cieszkowski's thought and the thought of Young Hegelians and Marx himself, who jointly criticized Hegel's philosophy as resistant to focusing the attention on future events ${ }^{5}$. Despite their common point of departure, Polish philosopher presented a different line of reasoning than Marx by rejecting the radical form of the change in the form of revolution, believing that it is not the proper way to implement “The Kingdom of Heaven” on Earth.(cf. Żółtowski 1922, 10-11). Due to the above, it is justifiable to present an answer to the question of how he understood the concept of change. Undertaking the analysis of that issue, we should be aware that this concept as conceived of by Cieszkowski may seem incoherent. It is because the issue of future and the changes related to it was present mainly in Prolegomena to a Historiosophy and Our Father; yet, it was accentuated differently in each of them.

Comparing the above-mentioned expectation of the advent of the new times with the contents of Prolegomena to a Historiosophy, what seems disturbing and making us wonder is the words referring to "the performers of history", who come into the scene at the moment of the materialization of the epoch of act (Cieszkowski 1972, 12). The phrase might prove to be confounding: who did Cieszkowski mean, mentioning the actors acting for

5 We do not mean to give any ground to the common belief that Marx borrowed from Cieszkowski's philosophy. The intention is rather to point to coincidences between them. 
the sake of the materialization of the future. Confronting that thought with Marx viewpoint on the primacy of the working class in shaping the face of the new time, we should note that he is not pointing to proletariat as the performers of the historical agenda. We may suppose that Cieszkowski seems to be a representative of a typical Polish romanticist looking ahead for the emergence of a charismatic leader (Janion 2007, 395). It means that he represented a typically messianic understanding of the future, not following the clues specified by left Hegelians and utopian socialist. Cieszkowski's contemporary Edward Dembowski in his Thoughts about the Future of Philosophy (Myśli o przyszłości filozofii) claimed that messianism leads only to the adoration a charismatic leader's genius and not to real progress (Dembowski 1955, 372-373). As a consequence, messianism proclaimed by Polish romanticists did not lead to correlating the future with action and changes in the social realm (Janion 2007, 395). Assuming such a viewpoint, we must state that Cieszkowski did not take up the challenge by left Hegelians and Marxism taking shape at that time. Instead Cieszkowski was in favour of the romantic image related to the fight for the future.

The lack of clarity in the attitude to "the performers of history" is interestingly continued in Our Father, in which the philosopher does not entirely dismiss social issues. As we can read:

Here is before our eyes, the unanticipated miracles of industry - here are the unthought - of treasures of science - here are still growing traces of huge and hectic labour; - here are the luxuries of which the Sybarites could never think of - here are the forces that the imagination could not even attribute to the fairy-tale Titans (Cieszkowski 1922, 1-2).

On the basis of the sentences quoted, one can get the impression that Cieszkowski directly refers to the issue of the working class (Sajdek 2008, 94) and the dynamically burgeoning capitalism. It is worthwhile to pay attention to the fact that his thoughts related to the issues of working class are quite general and do not indicate the unambiguous inclination to follow Young Hegelians and neither do they indicate calling for radical social (and political) changes. What it all means is that by not sharing the enthusiasm 
for revolution, he was trying to imagine the advent of the new epoch as coming shortly. The difference is that opposite to the horizontally oriented Hegelian leftists, he was in favour of vertical visions of utopian socialists. It should be emphasized that the issue of a working class was presented by Cieszkowski as the one in need of change and intervention but not by means of the concepts approximating Marxist "alienation" and "class conflicts". What is more, he even thought that the pathway beaten by the revolution will not lead to the solution of social injustice and neither will it make the new happy epoch more feasible. The evidence for the above is quite a long excerpt from Our Father:

And besides to all that, the populace and populaces -desire - and moan characteristically! - why was all that for? What is it leading? What is the gain of the science by scholars - what has the labour of working class gained? - what has the gold of the rich bought, - what has the bravery of nations fought - what have the tears of so many nations washed away? -Holy God - what is happening in the world? What had happened once in history is recurring again- but it will not occur anymore as long as humanity is humanity: the second "solstice" of humankind. The old world is dying - and the new one is being born - the third world is taking shape (Cieszkowski 1922, 2).

Juxtaposing two major works by Cieszkowki, we can believe that he was devoted to Hegelian philosophy and simultaneously he shared Hegel's fear related to revolution. However, he consistently developed his views related to the introduction to dialectics the idea of future and awaiting its advent in the ultimate form.

In his opinion, revolution seemed to be misguided not only due to the fact that it does not abolish suffering and it falsifies the picture of reality what we could have learned from the section above; but also due to dialectics itself. Especially in Our Father, he was pointing to the fact that revolution can by no means give rise to the introduction of the new epoch. Strictly speaking, reforms and revolutions are not the foundations of a new edifice but only the dismissal or the rearrangement of the old one (Cieszkowski 1972, 34 and 168; Cieszkowski 1923a, 181). 
It means that revolution, when conceived of within the framework of dialectics, proves to be only an antithesis and should not be considered synthesis. In other words, by negating the present we only express its "erratic movements" (Cieszkowski 1972: 41), and we do not step into the future. The emergence of the new epoch in the future should be characterized by the appearance of new so-far unknown values and attitudes. It is worth adding that they are not - unlike in Marxism - attitudes expressed politically but spiritually. Assuming such a manner of understanding Cieszkowski's thought, we can claim that his criticism of revolution is coherent and consistent. After all, he expressed it not only in Our Father, but also in Prolegomena to a Historiosophy, where we can read that "the Kingdom of Heaven" may materialize only when the human action will be conscious, free and permeated with love (Cieszkowski 1972, 15-16). However, what is an issue here is the way in which its materialization is possible. What is more, treating Cieszkowski's religious inclination seriously, it can be only some total change that can give rise to establishing the new epoch, while the total change proves to be nothing else than revolution itself. Trying to understand the decisive criticism of revolution and the simultaneous assumption of the image of the total change, we must bear in mind that what we have here is two realm: the political and the spiritual one. The former, as we remember, could not give rise to initiating - essentially - the new time. On the other hand, the latter, in Cieszkowski's opinion, is able to attain that goal. However, we must admit that the introduction of the total change may be realized only as a "leap", reminiscent of Marxian "leap into the kingdom of freedom" (cf. Walicki 1996, 26). Thereby, we can say that the concept of a total change in the form of the vision of "the Kingdom of Heaven" on Earth is nothing else than a revolution. It must be added that it is a revolution of spiritual nature.

Correlating the future with freedom and awareness has one more interesting aspect. What is mean here is focusing on the spiritual and not on the political dimension of the transformation of reality. The distinction between politics and spirituality is so vital because without it we would be unable to comprehend more precisely what he had meant by correlating the 
future with the freedom and awareness. On the political plane - contrary to what Marxism suggests - action does not cause the man to be liberated from the harassing fate and does not contribute to extending the knowledge of humankind. That is because he or she does not become a formulator of that new epoch but of a new political hegemony. It should be added that Cieszkowski only hints at such an understanding without introducing further explanations of the key concept in this context, that is "hegemony". The most conspicuous hint is his presentation of the dialectical movement of the emergence of dominating (or rather leading) political groups, which after all emerge only as antithesis but not as synthesis (cf. Cieszkowski 1972, 25 and 83). The lack of synthesis results from the fact that revolutionary movements are not characterized by achieving the state of knowledge on the essence of the world and the involvement of a human in it (Cieszkowski 1923b, 149). What should be understood by it is that only on the spiritual level, one might be liberated from the present and conduct the total change enabling one to make the "Kingdom of Heaven" on Earth materialize.

\section{Conclusions}

Clive S. Lewis in The Screwtape Letters put a highly intriguing sentence: "Gratitude directs us towards the past, love towards the present, fear, greed and unchastity and ambitions towards the future” (Lewis 1993, 86). That thought in the context of Cieszkowski's philosophy of future might instill some uneasiness and might pose the question whether it is worthwhile to be open to the future? It is because that openness includes the act of awaiting the future. The latter, in turn, might be expressed in striving to realize "the new time" being manifested in greed, unchastity, and - as might infer from Lewis' intentions - dishonourable ambitions. However, the openness to the future - if we listen carefully to the words pronounced by Polish philosopher - expressed mainly hope. The hope for dreams about the a better world coming true. Also Marx' thought contains that hope, Marx' thought being coinciding with Cieszkowski's idea, which is the belief that we have nothing to lose except for our chains (Marks 1976, 125). The 
difference is that priority is a revolution on the spiritual level, which can lead to alterations in interpersonal relations (also international relations). Thus, as opposed to Marx' considerations postulating first and foremost the changes in the socio-economic (and political) realm.

Eventually, it is worth to emphasize that Cieszkowski had a difficulty with transcending the forms of reasoning imposed by the epoch he lived in. That is why the question of future was not delineated as clearly as we might wish. Because - despite the assumptions related to the dialectical and religious modes of cognition - it cannot be well defined. Therefore, it is worthwhile to regard Cieszkowski's philosophy of future as making us open to what has not happened yet rather than to seeking the methodology of research on future. That is because future is not subject to epistemology but to the realm of hope (Szulakiewicz 2001, 45).

\section{References}

Cieszkowski, A. 1908. Prolegomena do historiozofii. Poznań.

Cieszkowski, A. 1922. Ojcze nasz. Wstęp poprzedzony traktatem o drogach Ducha, t. 1.

Poznań: Fiszer i Majewski.

Cieszkowski, A. 1923a. Ojcze nasz, t. 2. Poznań: Fiszer i Majewski.

Cieszkowski, A. 1923b. Ojcze nasz, t. 3. Poznań: Fiszer i Majewski.

Cieszkowski, A. 1972. Prolegomena do historiozofii. In: A. Cieszkowski, Prolegomena do historiozofii. Bóg i palingeneza oraz mniejsze pisma filozoficzne z lat 1838-1842. Warszawa: PWN.

Dembowski, E. 1955. Myśli o przyszłości filozofii. In: E. Dembowski, Pisma. 1844-1846 , t. IV. Warszawa: PWN.

Habermas, J. 1983. Heglowska krytyka rewolucji francuskiej. In: J. Habermas. Teoria i praktyka. Wybór pism. Warszawa: PIW.

Jakubowski, M. 1989. Czyn, przyszłość, naród. Poglądy filozoficzne Augusta Cieszkowskiego. Warszawa: PWN.

Janion, M. 2007. Gorączka romantyczna. Gdańsk: słowo/obraz terytoria.

Keller, J. 1948. Czyn jako wyraz postawy moralnej Augusta Cieszkowskiego. Lublin: Towarzystwo Naukowe KUL.

Kołakowski, L. 2000. Główne nurty marksizmu. Powstanie, t. 1. Poznań: Zysk i S-ka. Lewis, C. S. 1993. Listy starego diabła do młodego. Warszawa: PAX. 
Marks, K., 1975. Tezy o Feuerbachu. In: K. Marks, F. Engels. Dzieła, t. 3. Warszawa: KiW.

Marks, K., Engels, F. 1976. Manifest komunistyczny. Warszawa: KiW.

Sajdek, W. 2008. Postęp bez rozbioru. Podstawy teorii dynamizmu społecznego w filozofii Augusta Cieszkowskiego. Lublin: Wydawnictwo KUL.

Sojka, M. 1986. Neomesjanizm a recepcja Cieszkowskiego. Wrocław-Warszawa-Kraków-Gdańsk-Łódź: Ossolineum.

Szulakiewicz, M. 2001. Czas i to, co ludzkie. Szkice z chronozofii i kultury. Toruń: Wydawnictwo Naukowe UMK.

Walicki, A. 1972. Pisma Cieszkowskiego z lat 1838-42 na tle epoki. In: A. Cieszkowski. Prolegomena do historiozofii. Bóg i palingeneza oraz mniejsze pisma filozoficzne z lat 1838-1842. Warszawa: PWN.

Walicki, A. 1996. Marksizm i skok do królestwa wolności. Dzieje komunistycznej utopii. Warszawa: Wydawnictwo Naukowe PWN.

Żółtawski, A. 1922. Przedmowa. In: A. Cieszkowski. Ojcze nasz. Wstęp poprzedzony traktatem o drogach Ducha, t. 1. Poznań: Fiszer i Majewski. 